\title{
The Effect of Cadmium and Selenium on The Testicular Function and Tissue Injury in Male Rats
}

\author{
Talib HussenAli*,Ahmed BakerAli* \\ \& Soulaf Jabbar Kakel** \\ *Biology Department, Education college , Mosul University \\ **Physiology Department, Veterinary college, Mosul University
}

\section{الخلاصة}

تم دراسة تأثير الجرعة تحت المميتّة من كلوريد الكادميوم (7.ملغم / كغم مسن وزن

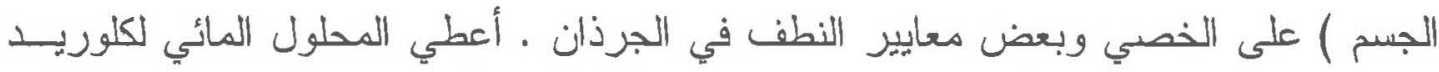
الكادميوم عن طريق الفم لذكور الجرذان الناضجة ( أوز انها 250-300 غم ) ولمدة 28 يوما

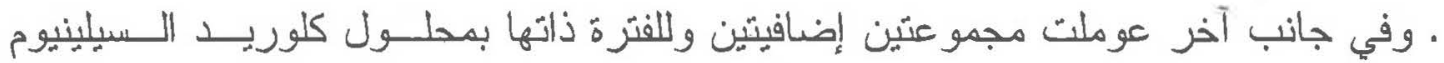

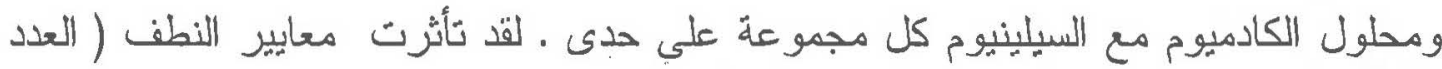
الكلي للنطف ، والنسب المئوية للنطف المشوه والميتة ) وكان التأثير معنــوي( 0.05 > P )

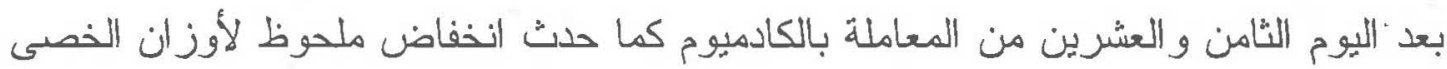

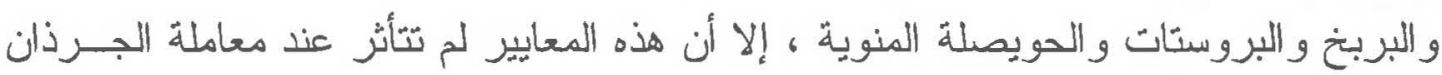

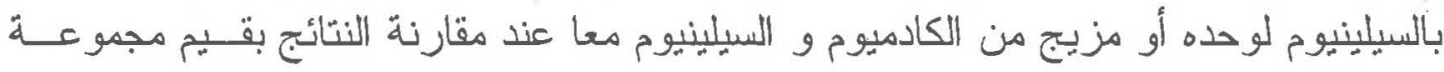

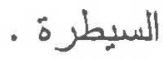

أظهرت الدر اسة النسيجية المرضية ضرر في أنسـسجة خـصـي الفئـران المعاملـــة بالكادميوم بينما اظهر السيلينيوم تأثير ا وقائيا للجرذان المعاملة بالكادميوم مع السيلينيوم .

\section{Abstract}

The effect of the sub lethal dose of cadmium chloride $\mathrm{CdCl}_{2}$ $7 \mathrm{mg} / \mathrm{kg} /$ body / weight ) was investigated on the testis and some sperm parameters in rats. .To evaluate the effect of cadmium exposure as $\mathrm{CdCl}_{2}$, was orally administered to mature male rats $(250-300 \mathrm{~g} /$ body weight $)$ for 28 days and the effects on the sperm count, sperm motility, sperm abnormality, sperm death percentages and testes weight, as well as testicular histology were observed. To evaluate the beneficial action of Selenium against Cadmium chloride-induced reduced sperm count and sperm abnormalities and testes injury in albino rats, an additional two groups of rats were treated for same period with $\mathrm{SeCl}_{2} 8 \mathrm{~m} / \mathrm{kg} /$ body

\footnotetext{
'Presented at the first conference on Biology, University of Mosul ,college of Education, 4-5 September 2007
} 
weight ) and $\mathrm{Cd}-\mathrm{Se}$ combination 'respectively to determine the reversibility of $\mathrm{Cd}$-induced changes

The sperm counts, sperm motility, sperm abnormality and sperm death percentages were significantly decreased following $28^{\text {th }}$ day of $\mathrm{CdCl}_{2}$ treatment, but were unaffected by $\mathrm{Se}$ and $\mathrm{Cd}-\mathrm{Se}$ exposures. The testicular, epididymis, prostate and seminal vesicle weight were noticeably reduced with Cd-treatment as compared to control. The changes caused by cadmium are mostly recovered by Se administration. Cadmium chloride exposure injures the fertility parameters of male rats and the effects are reversible due to Se supplementation. On the other hand, co-administration of $\mathrm{Se}$ at the above mentioned dose to Cadmium treated rats led to the most significant decline in testes tissue damage along with elevated sperm count and reduction in the percentage of abnormal sperm population. The protective action of $\mathrm{Se}$ and the antagonistic effect of both Se and Cadmium induced testes tissue damage are discussed.

\section{Introduction}

The roles that heavy metals play in the etiology of reproductive pathology debated for several decades [1]. Few studies were undertaken the effects of different inorganic and organic oxidant substances on the rats testes were available. Recently the effects of these oxidants substance on the testicular gametogenic activities in relation to oxidative stress in rats were investigated [2] and [3]. Results of these studies demonstrated the treatment by different oxidant substances resulted in significant reduction in relative organs weight (testes, epididymis, prostate and seminal vesicle ) in which subsequently affect the sperm production and motility .Moreover, Latchoumycandane, et al,${ }^{[4]}$ results showed that the co- administration of the antioxidant ( vitamin E ), prevented significant changes in the antioxidant systems in the epididymis and Epididymal sperm and prevent alteration in sperm count and motility .

Cadmium is an extremely toxic environmental contaminant that causes the production of reactive oxygen species( ROS )such as hydroxyl radicals, superoxide anions, nitric oxide and hydrogen peroxide[5], cadmium - induced oxidative stress is thought to play an important role in the pathogenesis of numerous degenerative diseases[6]. There are several hypotheses that suggest how reduced male fertility may result from incorporation of heavy metals into testes [7]. One hypothesis suggests that the presence of highly bound cadmium may prevent normal disulfide bond formation within and among protamines during final stage of sperm maturation. The disruption of this process may lead to lethal effect[8]. However, the information suggesting the involvement of heavy metals in the etiology of reduced male fertility has been elucidated. 
It is generally believed that oxidative stress and damage affect the organism when the generation of ROS products exceeds the capacity of the cells to protect or repair themselves [9] .Selenium (Se) is an essential dietary micronutrient required for maintenance of male fertility. Exposure to cadmium has been reported to reduce male fertility in rodent [10]. Other experimental evidences successfully relate the lead-induced reactive oxygen species (ROS), which damage the cell causing pathological problems [11] ROS, in general, heavy metals are capable of chemically altering all major classes of biomolecules like proteins, lipids, and nucleic acids [12] .

The aim of the present study was to evaluate the effect of sub lethal dose of cadmium on the testicular function of rats that have been treated to cadmium orally and its subsequent histopathological effect on testes and their protection by antioxidants such as selenium diet using albino rats as an experimental animals .

\section{Materials and Methods}

Experiments were performed on the adult male albino rats (weighing $250-300 \mathrm{~g}$ ). Animals were housed in laboratory and maintained at room temperatures $\left(25^{\circ} \mathrm{C}\right) . \mathrm{CdCl}_{2}$ was freshly dissolved in deionized water and the desired concentrations diluted from the stock solution $(7 \mathrm{mg} / \mathrm{L})$. Before supplementation, male rats were divided into a control and three experimental groups (groups of rats $n=5$ ), all were fed normal chow diet ad libtum, but $\mathrm{Cd}$ and Selenium were administrated by oral gavage in the experimental groups. The first group was served as vehicle (untreated control), the second group supplemented $7 \mathrm{mg} / \mathrm{kg} / \mathrm{b} . \mathrm{w}$ $\mathrm{CdCl}_{2}$, and the third group supplemented mixture of equal volume $\left(7 \mathrm{mg} / \mathrm{kg} / \mathrm{b} . \mathrm{wCdCl} \mathrm{Cl}_{2}+8 \mathrm{mg} / \mathrm{kg} / \mathrm{b}\right.$.w selenium chloride) and the fourth group supplemented. $8 \mathrm{mg} / \mathrm{kg}$ selenium chloride

All animals were caged in polypropylene cages to avoid extraneous trace element contamination. They were weighted and examined daily and food and water were recorded for each animal. At the end of the experiments (28 days) animals were killed by anesthetic overdose using ether. Sperm counted, sperm abnormality and perm death were recorded. The Body weight increasing percentage was calculated by Diniz, et al, ${ }^{[13]}$ formulae with modification:

\section{Somatic indices $(\mathrm{SI})=($ total body weight $/$ Initial body weight $) X 100$}

The testes parameters (Testes, Epididymm, Prostat and Seminal vesicles) were calculated $\mathrm{mg} / 100 \mathrm{gm}$ body weight in order to provide information on the testes conditions.For seminal fluid examination the epididymis was dissected out and squeezed in 5\% formal sodium bicarbonate diluted with $1-10 \mathrm{ml}$ of the same solution and examined under 
the microscope using a Nubauer hemocytometer. For sperm morphology and activity the epididymis was placed in formal sodium bicarbonate, cut into pieces and squeezed out to remove sperm. Epididymal fragments were removed and cleaned, the solution diluted $(1-10)$ in the formal sodium bicarbonate, mixed thoroughly and allow to settle for 15 mints before examined under the light microscope. The sperm count was calculated. For sperm abnormality and death percentage calculation the sperm smear was dried in air, stained with nigrosin and examined under the light microscope, the morphological appearance and the percentage of abnormal were recorded.

\section{Light microscopic preparation}

For light microscopic preparation, testes were dissected out and small portion of organs fixed in Bouin's solution for $16 \mathrm{~h}$ and subsequently placed in $70 \%$ ethanol. Dehydrated in ethanol series, cleared with xylene, infiltrated and embedded in paraffin wax. Thin section $(7 \mu)$ were cut and stained with hematoxylin - eosin for histological examination.

\section{Statistical analysis}

The data were analyzed using one way - ANOVA with a Duncan post test (SPSS, V.11.5 for windows) for significant differences.

\section{Results}

Table( 1 ) shows that body weight was decreased significantly( $p<0.05$ ) in all samples taken at the $28^{\text {th }}$ day after $\mathrm{Cd}$ - treatment compared to the control as well as to $\mathrm{Se}$ and $\mathrm{Se}-\mathrm{Cd}$ combination treatment - Testes, Epididymis, Prostate and Seminal vesicle weights were decreased significantly $(\mathrm{p}<0.05)$ in all samples taken at the $28^{\text {th }}$ day after treatment compared to the control, Se and $\mathrm{Se}+\mathrm{Cd}$ treated animals. Rats group treated with Se showed noticeable higher) testes weight compared to both $\mathrm{Cd}$ - treated and un-treated group. Moreover, the Cd-treated group treated additionally with Se showed no significant changes in testes, epididymis, prostate and seminal vesicle weight compared to the Se and control rats group. 


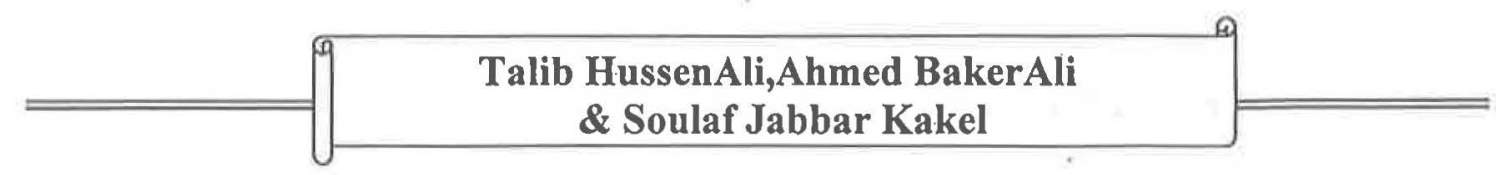

TABLE (1). Somatic indices .

\begin{tabular}{|c|c|c|c|c|c|}
\hline \multicolumn{6}{|c|}{ Body $(\%)$ and organ weight $(\mathrm{mg} / 100 \mathrm{gm}$ b.w ) of control and treated groups of rats } \\
\hline \multirow{2}{*}{ Groups } & \multirow{2}{*}{$\begin{array}{c}\text { Body } \\
\text { weight } \%\end{array}$} & \multicolumn{4}{|c|}{ Organ Weights (mg/100gm b.w) } \\
\hline & & Testes & Epididymis & prostat & $\begin{array}{c}\text { Seminal } \\
\text { Vesicle }\end{array}$ \\
\hline Control & $11.52 \pm 0.409$ & $377.26 \pm 12.61$ & $110.5 \pm 1.5$ & $139.3 \pm 6.9$ & $32.3 \pm 3.16$ \\
\hline Cd-treated & $8.88 \pm 1.397^{*}$ & $320.2 \pm 28.09^{*}$ & $91.4 \pm 2.2^{*}$ & $24.1 \pm 7.9^{*}$ & $27.6 \pm 4.02^{*}$ \\
\hline Se-treated & $11.85 \pm 0.911^{\mathrm{NS}}$ & $401.68 \pm 13.5^{\mathrm{NS}}$ & $111.8 \pm 2.8$ & $42.5 \pm 6.1^{*}$ & $33.4 \pm 3.2^{\mathrm{NS}}$ \\
\hline Cd-Se treated & $11.51 \underset{\mathrm{NS}}{ \pm} 0.772$ & $376.69 \pm 6.6^{\mathrm{NS}}$ & $\begin{array}{c}110.4 \pm 3.02 \\
\mathrm{NS}\end{array}$ & $139.2 \pm 3.5^{\mathrm{NS}}$ & $32.3 \pm 5.1^{\mathrm{NS}}$ \\
\hline
\end{tabular}

The sperm count profile of the Cd-treated rats was reduced significantly $(p<0.05)$ as compared to the control group while the Se supplemented group showed a significantly $(p<0.05)$ higher sperm count compared to the unsupplemented treated group and the $\mathrm{Cd}$ supplemented group Fig ( 1).

$\square$ control $\square \mathrm{Cd} \mathrm{GSe} \mathrm{Cd}+\mathrm{Se}$

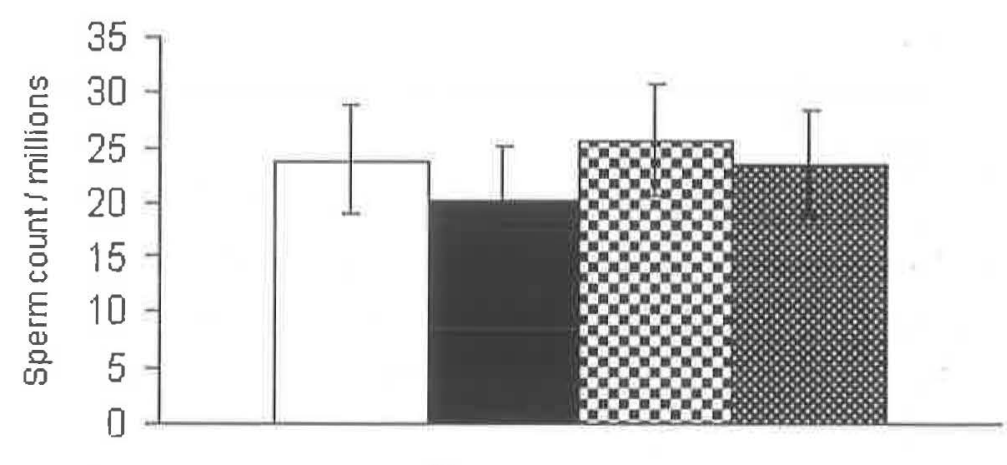

Treatments

Fig. (1) Sperm count of rats treated with Cd- $7 \mathrm{mg} / \mathrm{kg} / \mathrm{b} . \mathrm{w}$ and $8 \mathrm{mg} / \mathrm{kg} / \mathrm{b} . \mathrm{w} \mathrm{Cd}+\mathrm{Se}$ combination

Fig ( 2 ) illustrated the analysis of sperm samples of $\mathrm{Cd}, \mathrm{Se}$, and $\mathrm{Cd}-\mathrm{Se}$ treated rats . A significant $(p<0.05)$ decrease in sperm motility was found in the Cd-induced rats compared to both controls and Se-treated animals In addition the Cd-treated rats showed a significant increase in sperm abnormality and elevation in sperm death percentages . amorphous sperm , such as hook-less and curly and looped tails were seen in Fig (3) other various sperm shape morphologies, include lance-shaped, banana- 
shaped and balloon-shaped also observed but in a closer examination ( not seen in fig. 3 . Furthermore, the $\mathrm{Se}$ and $\mathrm{Se}-\mathrm{Cd}$-treated rats group showed a significantly lower $(\mathrm{p}<0.05)$ sperm abnormality and sperm death compared to $\mathrm{Cd}$-treated $(\mathrm{p}<0.05 \mathrm{Cd}$-treated animals.

\section{Doontrol acd BSe racd $+\mathrm{Se}$}

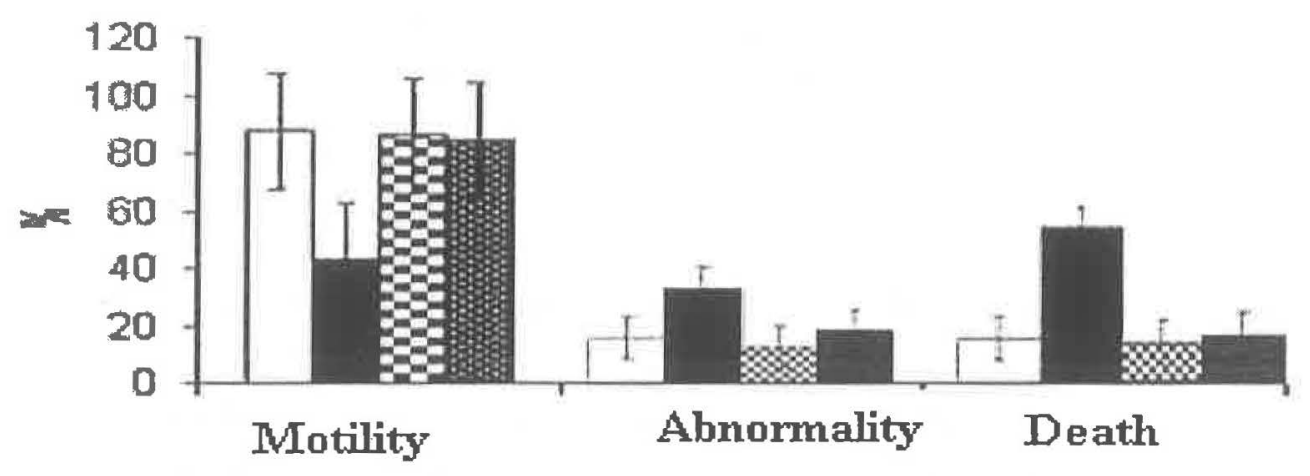

Fig (2) Sperm Motility, sperm abnormality and sperm death percentage.

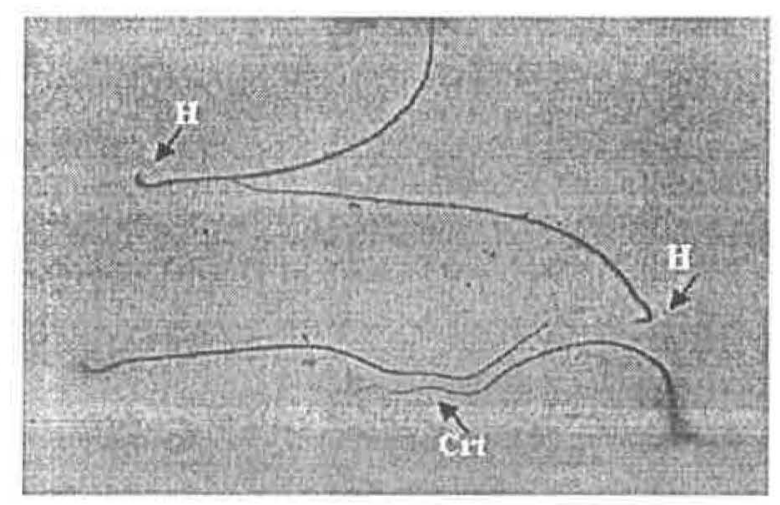

Fig (3) Sperms Morphology ( H : Hook shaped -Crt : Curly tail)

The male gonads of Cd-treated animals showed a severe bilateral atrophy, in which the basement membranes between the seminiferous tubules were detached. The seminiferous tubules considerably reduced in diameter and almost. entirely lined by spermatogonial cells and a few spermatocye cells noted. Differentiated spermatozoa could not be detected fig (4b). The alterations were reversible and spermatogenesis was restored by feeding the selenium-adequate diet fig (4c). 

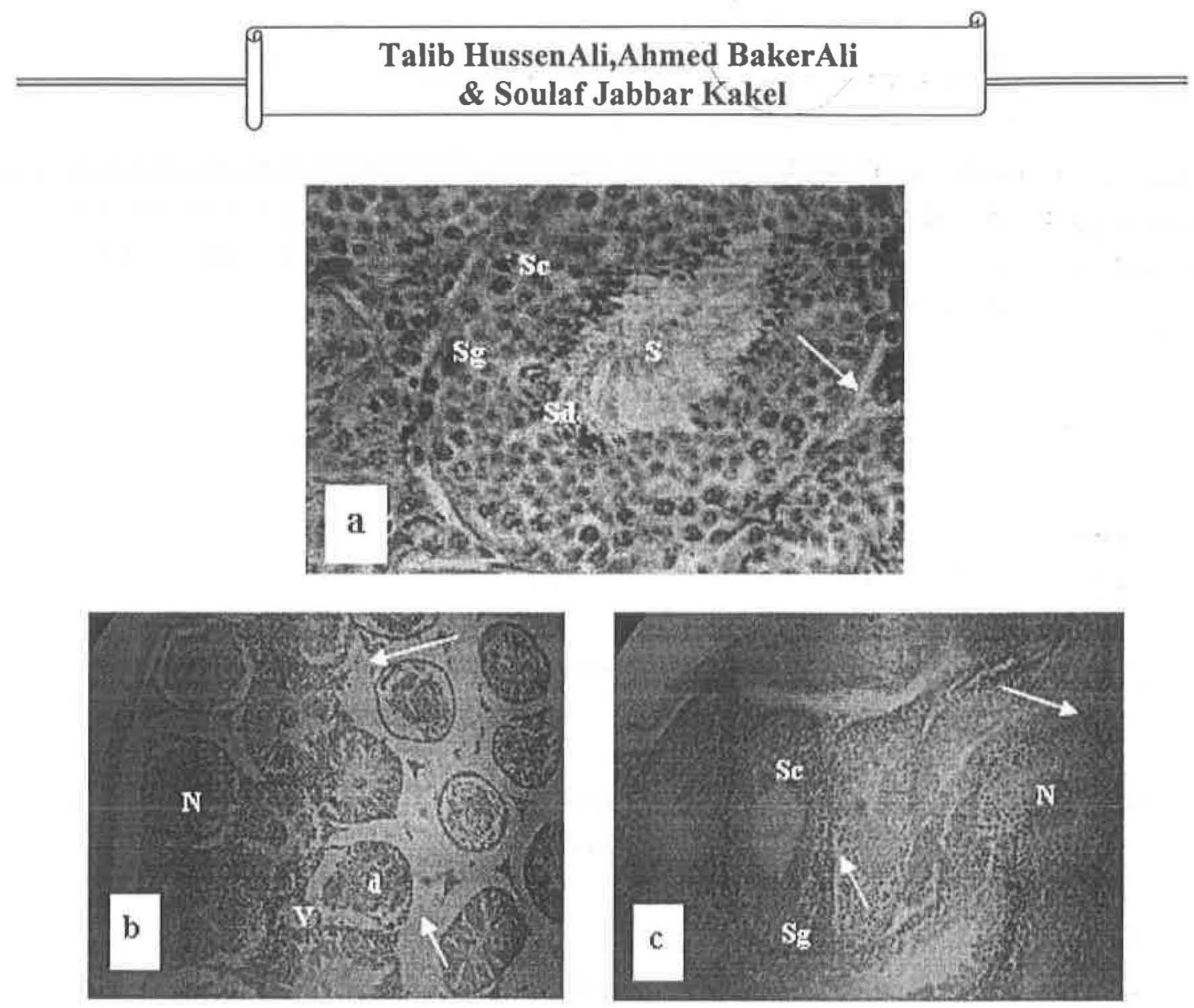

Fig(4). Section in rat testes a-untreated-control, b-Cd-treated and C-Cd+Se treated group (Sg-spermatogonia, Sc-spermatocye, Sd-spermtid, S-sperm, N-necrosis, V-vaculation, ddegeneration.

\section{Discussion}

Results in Figs ( 1 and 2 ) demonstrated reduction in sperm count, sperm abnormalities and sperm death percentage due to $\mathrm{Cd}$ - treatments, these abnormalities due to chemical mutagens are well documented [14] . In the light of this, the present cadmium chloride has been considered as a potent toxic substance causing formation of abnormal sperm and reduction in sperm population at higher doses $(7 \mathrm{mg} / \mathrm{kg} / \mathrm{b} . \mathrm{w})$ Our results including the abnormal sperm morphology (hook less and curly tail in fig.3) are in consistent with other results in that chemical mutagens effects inducing changes in sperm morphology [14] and [15]. Se supplementation of a group of cadmium chloride-treated rat, is associated with a significantly higher sperm count and a lower percentage of abnormal sperm population along with a concomitant lower testicular injury, compared to the Cd-treated rat group. Se is one of several antioxidative substance, which have been postulated to minimize testicular cytotoxic effects in animals treated with pesticides, chemical mutagens and xenobiotic [16] .Se supplementation to Cd-treated rat, in the present study, has remarkably lowered the incidence of abnormal 
sperm production and significantly increased the sperm count, with a decrease in testicular injury. This clearly indicates that Se efficiently prevents germ cell destruction or injury by inhibiting the generation of ROS. Behne,et $a{ }^{[17]}$ results indicate that testicular morphology and function of rats affected by severe selenium deficiency and that the element is necessary for normal development of spermatozoa . In general , Se prevents the degeneration of male germ cells by minimizing peroxidation [18]. The exact mechanism of the protective action of Se against ROS-induced genotoxicity is not in detail understood.

Data of table (1) showed an obvious reduction in body weight, testes, epididymis, prostate and seminal vesicle due to Cd-treatment. This observation suggests that $\mathrm{Cd}$ - treatment induced significant metabolic alterations in the testes, epididymides, prostate and seminal vesicle, of rat. Hence, the observed sperm count decrease in the Cd-treated rat may be due to direct interaction of ROS with the sperm cell membrane. The present finding is also consistent with previous studies [19]. Recently the effects of oxidants substance on the testicular gametogenic activities in relation to oxidative stress in rats were investigated. Ghosh, et al, ${ }^{[2]}$ and Chitra, et al , ${ }^{[3]}$ results are demonstrated that the treatment by different oxidant substances resulted in significant reduction in relative organs weight ( testes, epididymis, prostate and seminal vesicle ) in which subsequently affect the sperm production and motility .Data in table1. also revealed the beneficial effects of selenium supplementation on testes, epididymis, prostate and seminal vesicle of $\mathrm{Cd}$ - treated male rat .The supplementation of Se produced complete recovery. On the other hand, the Co-treatment of rats with $\mathrm{Cd}$-Se was found to be very beneficial but incomplete recovery observed. Selenium deficiency also reduces testis size, and prolonged deficiency results in atrophy of the seminiferous epithelium [17], [20], [21] and [22]. Other study found that vitamin C supplement decrease the testicular relative weight as compared to both normal and Cd treated rats [23].

Results from Fig (4) indicate that testicular morphology and functions are affected by $\mathrm{Cd}$ toxicity and recover by selenium supplementation and that the element is necessary for normal development of spermatozoa. The higher membrane lipid content of testes is presumed to make them more vulnerable to oxidative stress [24], Moreover; $\mathrm{Cd}$ is capable of generating and promoting free radical reactions to a different extent in different tissues. A significantly reduced sperm count in Cd-treated rat after the treatment clearly shows the elimination of germ cells at different stages of development and points to damaging $\mathrm{ROS}$ generated through $\mathrm{Cd}$ catalysis. In fact, oxidative damage to polyunsaturated fatty acids of cell membranes has long been considered to result in the impairment of membrane fluidity and 
$\sqrt{9 \begin{array}{c}\text { Talib HussenAli,Ahmed BakerAli } \\ \text { \& Soulaf Jabbar Kakel }\end{array}}$

permeability leading to the efficient damage of germ cells, spermatozoa and mature sperm. Hence, the observed sperm count decrease in the $\mathrm{Cd}$ treated rat may be due to direct interaction of ROS with the sperm cell membrane. The present finding is also consistent with previous studies. Latchoumycandane, et al,${ }^{[4]}$ and Acharya, et al, ${ }^{[19]}$ results showed that the co- administration of the antioxidant ( vitamin E), prevented significant changes in the antioxidant systems in the epididymis and epididymal sperm and prevented alteration in sperm count and motility. Thus elucidating their ameliorative role in recovery from toxic effects $\mathrm{Cd}$ on the reproductive functions and fertility becomes important. 


\section{The Effect of Cadmium and Selenium....}

\section{References}

[1]_Bench, G; Corzett, M.H; Martinelli R and R. Balhorn.. Cytometry 35 : 30-36. (1999)

[2]Ghosh,D;Das,S.S;Maiti,R;Jana,D and Das,U.B..Rerod.Toxicol.16 (4):385-390. (2002).

[3] Chitra, K.; Latchoumycandane, C. and Mathur, P.P. Toxicology. 185 (1-2): 119-127. (2003).

[4]Latchoumycandane, C.; Chitra, K.C.; and Mathur, P.P. Reprod. Toxicol. 16 (2) $83-87$ (.2002).

[5]Stohs, S. T; Bagchi, D; Hassoun, E and Bagchi, M. J. Environ. Pathol . Toxicol. Oncol. 20 (2): 77 - 88. (2000).

[6]. Saxena, D.K Hussain, T, Lal B and. Chandra, S.V. Ind Health 24: 105-109. (1986).

[7]Johansson, L and Pellicciari, C.E. Toxicol. 51: 11 -24. (1986).

[8]Shelby, M.D; Cain, K.T; Hughers,I.A; Braden,P.W and . Generoso, W.M...Mutat.Res. 173: 35 - 40. (1986)

[9] Yu, B.P.Physiol Rev 74: 139-162 . (1994).

[10] Thomas, J.A; and Brogen, W.C. Am.J.Ind.Med.4: 127 -11. (1983)

[11]Halliwell B.and. Gutteridge, J. Mol Aspects Med 8: 89-93. (1985).

[12]Davies, K.J. Lin S.W and. Pacifici, R.E. J Biol Chem 262: 99149920. (1987).

[13]Diniz, M.s; Peres, I; Antoine, I.M; Falla, J and Pihan, J.c.Ecotoxicology and environmental safety. 62:427 - 435. (2002).

[14] Wyrobek A.J., and Bruce, W.R.hem Mutagen 5: 275-285. (1978).

[15]Mishra, M and Acharya, U. R. . J.Trace Elements in Medicine and biology, 18 (2):173-178. (2004).

[16] Khan, P.K. and Sinha, S.P. Mutagenesis 11: 33-36. (1996).

[17]Behne D, Weiler H and Kyriakopoulos, A. Journal of Reproduction and Fertility 106 291-297. (1996)

[18]. Burton, G.W; Joyce A., and. Ingold K.U. Lancet 2 270-280. (1982).

[19] Acharya, U.R.; Rathore R.M and Mishra, M. Environ Toxicol Pharmacol 13: 9-14. (2003).

[20] Sprinker L.H, Harr J.R, Newberne P.M, Whanger PD and Weswig P.H. Nutrition Reports International 4 : 334-335 . (1971) .

[21] Maiorino M, Flohe L, Roveri A, Steinert P, Wissing J.B and Ursini „F Bio Factors 10: 251-256. (.1999).

[22]Lyalli,V,Chauhan,V.P;Prasad,R;Sharkar,A.KandNath,R.Toxocology. Lett.42: 131-135. (1982).

[23] Georgiou, M. ; Perkins $M$ and. Payne, A.H. Endocrinology 121:1390-1399.

(1987).

[ 